\title{
Views of Science Teachers on Design, and Application of Laboratory Experiments and the Learning Process*
}

\author{
Betül AYDIN** $\quad$ Oktay BEKTAŞ*** Fulya Öner ARMAĞAN ${ }^{* * * *}$
}

Received: 23 June 2015 Accepted: 20 September 2015

\begin{abstract}
It was aimed to determine science teachers' views on the design and application of experiments and the learning process. This qualitative study has a phenomenological design. Data were collected from three science teachers in the fall of 2014-2015 academic year. Semi-structured interviews were used to collect the data. Descriptive analysis was conducted, and codes and themes were generated based on the findings Based on the results, science teachers stated that academic achievement of students increased when experiments were applied in the science lessons. They also said that students were eager to conduct experiments when they had sufficient material and time. Moreover, teachers stated that meaningful learning occurred when experiments were applied in the science classes. Students should be made active in the science lessons using daily materials.
\end{abstract}

Keywords: Science education, qualitative research, phenomenology, experiment.

\section{Extended Abstract}

Purpose and Significance: Science is a way of thinking on experiments. Therefore, emphasis on experiments in science classes allows students to develop of science process skills. Science teaching based on experiments teaches students to ask questions and solve problems. Therefore, laboratories are important place in science education. Science educators have indicated that more learning takes place through experiments. Hence, science teaching should be applied in connection with the events in nature or daily life. Activating students by asking questions, providing solutions, and connecting with daily life may make science hard course. Overcoming this difficulty will be possible with qualified teachers who knowing and applying contemporary teaching approaches since learning is a common aim of students and teacher. Laboratory is an important factor on the learning of students. Therefore, the preparation and qualification of teachers and interaction between students and teacher in laboratories is very important in terms of meaningful learning. In the literature, although there are more studies investigating the effects of laboratory based instruction on science learning, there are limited number of studies investigating science teachers' opinions regarding

\footnotetext{
* This study has been accepted for poster presentation at the International Congress on Education for the Future: Issues and Challenges- ICEFIC 2015.

** MA Student, Erciyes Üniversitesi, Kayseri, Türkiye,bt1006@gmail.com

*** Sorumlu Yazar: Yrd. Doç. Dr., Erciyes Üniversitesi, Kayseri, Türkiye, obektas@erciyes.edu.tr

**** Yrd. Doç. Dr., Erciyes Üniversitesi, Kayseri, Türkiye, onerf@erciyes.edu.tr
}

\section{Citation Information}

Aydın, B., Bektaş, O., \& Armağan, F. Ö. (2016). Deneylerin uygulama, tasarlama ve öğrenme sürecine ilişkin fen bilimleri öğretmenlerinin görüşleri. Kuramsal Eğitimbilim Dergisi [Journal of Theoretical Educational Science], 9(3), 476-496. 
designing and application process of experiments in science lessons and students' learning on experiments. Therefore, purpose of the present study was to determine opinions of science teachers regarding designing and applying experiments and student learning from these experiments. The following research question was addressed: "What are the opinions of science teachers regarding designing and application process of experiments in science lessons and students' learning from experiments?"

Methods: This qualitative study was a phenomenology. Purposive sampling was used to determine participants. Participants were two females (O2 and O3) and one male (O1) who studying as science teacher in Kayseri in 2014-2015 fall semester. Semi-structured interviews were used as data collection instruments. Interview questions consisted of utilizing the literature. These questions were examined by two science education experts to ensure content validity. All interviews were transcribed. For data analysis, transcribed data was read and codes and themes were formed based on findings and expert opinions. These themes were "activities, application environment, difficulties in application, interest to experiments, class teacher, teacher competence, resource type, student participation, contribution of experiment, attitude and achievement, relationship with other courses, and aim of experiments". To ensure internal validity, copy of interview was given to interviewee to confirm interview data. To ensure external validity, detailed information about participants, method, and results was given in the study. Moreover, results were given by means of direct quotations without making interpretations.

Results: Based on results, all science teachers stated that success of students can be increased if teachers use experiments in their lessons. Moreover, they emphasized that although students are volunteers to make experiments, lack of materials is an important problem to conduct experiments. Also, three participants stated that they had difficulties during application of experiments because of insufficient time and unfavorable environment. Likewise, they stated that science experiments contributed to the development of science process skills of students, provide a better understanding of the topics, and develop their academic and social aspects. Finally, they stressed that students could link between daily life and science topics with the experiments. O-1 stated his thoughts on these results as "Scientific thinking processes of students develops through science experiments. Moreover, experiments ensure academic contribution to the students. When the experiments are used in science lessons, students like their teachers much more, socialize, and have positive feelings toward experiments". Besides, all participants stressed that experiments make positive changes in students' attitudes towards the science. The statements of O-3 during the interview support this case; "There are interesting experiments and students who do not participate in the course are coming with me to make contribution to the experiments". Some implications were discussed. For instance, studies investigating how science 
teachers apply experiments in their courses should be conducted to promote meaningful learning of students.

Discussion and Conclusions: Science teachers stated that academic achievement of students increased when experiments were applied in the science lessons. They also said that students were eager to conduct experiments when they had sufficient material and time. Moreover, teachers stated that meaningful learning occurred when experiments were applied in the science classes. Likewise, they stated that cooperation with the mathematics course increases the contribution of the experiments on learning. Students should be made active in the science lessons using daily materials. Also, experiment materials should be provided in schools. Moreover, appropriate laboratories should be provided to teachers for the application and design of experiments. In this study, semistructured interview was used as data collection tool. However, observation and document analysis can be used to ensure triangulation. 


\title{
Deneylerin Uygulama, Tasarlama ve Öğrenme Sürecine İlişkin Fen Bilimleri Öğretmenlerinin Görüşleri*
}

\author{
Betül AYDIN ${ }^{* *} \quad$ Oktay BEKTAŞ⿻**** Fulya Öner ARMAĞAN ${ }^{* * * *}$
}

Makale Gönderme Tarihi: 23 Haziran 2015

Makale Kabul Tarihi: 20 Eylül 2015

\begin{abstract}
ÖZ: Bu araştırmada, öğretmenlerin, fen bilimleri derslerindeki deneyleri tasarlama, uygulama becerileri ve öğrenme sürecine ilişkin görüşlerinin saptanması amaçlanmıştır. Çalışmada nitel araştırma yöntemlerinden olgu-bilim deseni kullanılmıştır. Araştırma verileri 2014-2015 eğitim öğretim yılında fen bilimleri öğretmenliği yapan üç öğretmenden toplanmıştır. Veri toplama aracı olarak yarı yapılandırılmış görüşme formu kullanılmıştır. Veri analizinde ise betimsel analiz kullanılmış ve bulgular doğrultusunda uzman görüşü de alınarak kodlar-temalar oluşturulmuştur. Araştırmanın sonuçları, fen dersinde deneylerin uygulanmasının öğrencilerin akademik başarılarını artırdığı, öğrencilerin uygulama konusunda çok istekli olduğu fakat okullarda malzeme eksikliğinin olması ve uygulamaların çok zaman almasının deneyleri uygulamada ve tasarlamada önemli ölçüde problem oluşturduğu yönündedir. Ayrıca öğrencilerin matematiksel işlem becerilerinin olmadığı durumlarda da konu anlaşılsa bile sonuca doğru ulaşamadıkları için anlamlı öğrenmenin sağlanamaması araştırmanın bulgularındandır. Deneylerle beraber yürütülen fen bilimleri dersi konunun daha iyi anlaşılmasını sağlayacağı için, araç-gereç sıkıntısı olsa bile günlük hayattan kolay ulaşılabilecek malzemelerle derslerde öğrencileri aktif kılacak uygulamalara yer verilmesi önerilmiştir.
\end{abstract}

Anahtar kelimeler: Fen eğitimi, nitel araştırma, olgu-bilim, deney.

\section{Giriş}

Fen, deneysel ölçütleri, mantıksal düşünmeyi ve sürekli sorgulamayı temel alan bir bilim dalıdır (Millî Eğitim Bakanlığı [MEB], 2005). Fen öğretiminin temel amaçları, araştıran, eleştirel düşünebilen, günlük hayatla fen konuları arasında bağlantı kurabilen, karşılaştı̆̆ problemleri bilimsel yöntemlerle çözebilen ve bir bilim insanın bakış açısıyla bakabilen bireyler yetiştirmektir (Hofstein \& Lunetta, 2004). Feni öğretmek kadar öğrenmekte önemlidir. Bir başka ifadeyle, fen öğrenimi bilimsel metotları kullanarak bilgiye ulaşabilme ve üretebilme ve ayrıca bilimsel süreç becerilerini kullanabilmektir. Bilimsel süreç becerilerine sahip olan bir birey değişkenleri belirler ve değiştirir, gözlem yapar, hipotez kurar ve deney yapar, sinıflar, ölçer, verileri kaydedebilir, verileri kullanır ve yorumlar (Mabie \& Baker, 1996; Tan \& Temiz, 2003; Wilke \& Straits, 2005). Derslerde deney ve gözleme ağırlık verilmesi bilimsel süreç becerilerinin gelişmesini sağlar. $\mathrm{Bu}$ becerilerin gelişmesi ile deneyler konuyla ilişkilendirilebilir ve kavramlar zihinde anlamlı olarak yapılandırılır (Aktamış \& Ergin, 2007; Aktamış \& Şahin Pekmez, 2011; Huppert, Lomask, \& Lazarowitz, 2002; Mabie \& Baker, 1996; Tan \& Temiz, 2003). Bilimsel süreç becerileri kullanılarak anlamlı öğrenmeyi gerçekleştirmek için öğrencilerin sınıf içinde aktif olduğu öğretim stratejilerinin uygulanması gerekir (Myers, 2004; Wu \& Krajcik, 2006). Yapılandırmac1

\footnotetext{
* Bu çalışma "The International Congress on Education for the Future: Issues and Challenges- ICEFIC 2015" kongresinde poster sunusu olarak kabul edilmiştir.

** Yüksek Lisans Öğrencisi, Erciyes Üniversitesi, Kayseri, Türkiye, btl006@ gmail.com

*** Sorumlu Yazar: Yrd. Doç. Dr., Erciyes Üniversitesi, Kayseri, Türkiye, obektas@erciyes.edu.tr

**** Yrd. Doç. Dr., Erciyes Üniversitesi, Kayseri, Türkiye, onerf@erciyes.edu.tr
} 
yaklaşımı temel alan bu stratejiler öğrencilerin bilimsel süreç becerilerini geliştirmede etkin olan stratejilerdir. Örneğin, Arı ve Bayram (2011) çalışmalarında, yapılandırmacı yaklaşım esas alındığında geleneksel öğretim yöntemine göre öğrencilerin bilimsel süreç becerilerinin gelişiminin daha üst seviyelerde gerçekleşebildiğini ifade etmişlerdir. Bilimsel süreç becerileri öğrencilerin feni anlamlı öğrenmelerine katkı sunduğu gibi onların fen öğretimi sürecinde deneyler yaparak etkili öğrenmelerine ve yaratıcı düşünmelerine de katkı sağlamaktadır (Aydoğdu \& Ergin 2010; Chang, \& Weng, 2000; Güven \& Gürdal, 2002; Kanlı \& Yağbasan, 2008; Turpin, \& Cage, 2004 ). Bir başka ifadeyle, öğrenciler deneyler yoluyla feni yaparak ve yaşayarak öğrenirler. Deneyler yoluyla öğrenilen fen dersleri öğrencileri öğrenmeye güdüler ve onların fen öğreniminde istekli olmalarını sağlar. Ayrıca, deneyler yoluyla öğrenilen fen, öğrencilerin soru sormalarını sağlayarak ve araştırarak anlamlı öğrenmelerini artırır (Kang \& Wallace, 2005; Lagowski, 1989; Tiberghien, Veillard, Le Maréchal, Buty, \& Millar, 2001; Ulukök, Çelik \& Sarı, 2013; YÖK/Dünya Bankası, 1997). Fakat okullarda bu gerçeğe göre fen öğretimi yeterli seviyede yapılamamaktadır. Fen öğretiminin başarısız olmasının altındaki etken de fenin öğrencilere günlük hayatlarıyla ilişkilendirilmeden hazır bilgi halinde sunulmasıdır (Ünal \& Ergin, 2006). Bu nedenle, öğretim kademelerinin çoğunda fen bilimleri en çok zorlanılan derslerin başında gelir. $\mathrm{Bu}$ zorluğu aşmak ve fen derslerinde anlamlı öğrenmeyi sağlamak için yapılandırmacı yaklaşımı uygulayabilen nitelikli öğretmenlere ihtiyaç vardır (Appleton, 2006; Buluş Kırıkkaya, 2009; Hadson, 1988; Hançer, Şensoy \& Yıldırım, 2003; Kang \& Wallace, 2005). İyi bir fen bilimleri öğretmeni, öğrencilerinde anlamlı öğrenmeyi gerçekleştirmek için derslerinde yaparak ve yaşayarak öğrenmeyi vurgular ve derslerini deneysel aktivitelerle zenginleştirir (Hofstein \& Mamlok-Naaman, 2007). Ayrıca, bir fen bilimleri öğretmeni deneysel yöntem, araç ve gereçleri ile doğadaki olaylarla ve günlük yaşamdaki somut işlemlerle bağlantı kurar. Deneysel uygulamalar sayesinde bir fen bilimleri öğretmeni öğrencilerinin el becerilerini geliştirir. Ayrıca, öğrenciler bu aktiviteler yoluyla soyut kavramları somut hale dönüştürür, öğrendiklerini sorgular ve farklı durumlara uygular. Bir başka ifadeyle, deneyler yoluyla öğrenciler konuları ezberleme yerine, kendi yaptıkları deneyleri gözlemleyerek ve çıkarım yaparak anlamlı öğrenme gerçekleştirirler (Abrahams \& Millar, 2008; Myers, 2004). Ayrıca, gözlem sonucu elde ettikleri bulgulardan öğrendiklerini sorgularlar ve neden-sonuç ilişkisi aramaya başlarlar (Haury, \& Rillero, 1994). Dolayısıyla, bu süreçte fen bilimleri öğretmenlerine önemli görevler düşmektedir. Bu nedenle, Özmen (2004), fen eğitimi programlarının okullardaki uygulayıcıları olan öğretmenlerin çağdaş bilgi, beceri ve tutumlara sahip olarak yetiştirilmelerinin önemini vurgulamıştır. Yukarıda bahsedilen nedenlerden dolayı, fen bilimleri öğretmenin niteliği fen eğitim ve öğretiminde önem kazanmaktadır (Appleton, 2006; Demirci, 1993). Dolayısıyla, nitelikli fen bilimleri öğretmenleri bilimsel konulara ilişkin düşünceler üretebilecek öğrenciler yetiştirmelidir. Ayrıca, onların bilimsel süreç becerilerini geliştirebilmeli ve fen derslerinde öğrendiklerini onlara günlük yaşamlarında uygulatabilecek yeterlikte olmalıdırlar (Appleton, 2006; Van Driel, Beijaard \& Verloop, 2001). 
Yukarıda açıklandığı gibi, deneylerle fen öğretiminin öğrencilerin öğrenmeleri üzerinde etkili olduğu görülmektedir. Fakat deneylerin uygulama sürecinde öğretmenlerin karşılaştığı güçlüklerin neler olduğu (Coştu, Ayas, Çalık, Ünal, \& Karataş, 2005; Kanlı \& Yağbasan, 2008), öğretmenler açısından deney tasarımının ne derecede anlaşılır olduğu ve ders kitabında yer alan deneylerin dersin kazanımlarına uygun olup olmadığının da bilinmesi gerekmektedir (Geçer \& Özel, 2012; Gömleksiz \& Bulut, 2007). Ayrıca, öğretmenlerin laboratuvarı kullanmamalarının veya etkili bir şekilde kullanmamalarının da sebepleri araştırılmalıdır. Gürdal (1991) fen eğitiminde laboratuvar kullanımının okulun gelişmişlik ve sosyoekonomik düzeyi ile arttığını belirtmiş ve fen bilgisi öğretmenlerinin laboratuvarı kullanmama sebebi olarak okullarındaki malzemelerin yetersizliğini göstermiştir.

Alan yazın incelendiğinde, laboratuvar kullanmanın önemi ve gerekliliği üzerine çok sayıda çalışmaya rastlanmıştır (Erten, 1993; Hofstein \& Mamlok-Naaman, 2007; Hofstein, Nahum \& Shore, 2001; Kang \& Wallace, 2005; Uluçınar, Cansaran \& Karaca, 2004). Fakat öğretmenlerin deneyleri tasarlayabilmek için sahip olmaları gereken pedagojik alan bilgilerini, bu deneylerin uygulama sürecinde karşılaştıkları güçlükleri ve buna dair görüşlerini araştıran çalışmaların sayısı oldukça az bulunmuştur (Aydoğdu \& Ergin 2009; Güven \& Gürdal, 2002; Kılıç, 2003; Kocakülah \& Savaş, 2011). Dolayısıyla bu çalışmada, fen bilimleri öğretmenlerinin, fen deneylerini uygulama becerileri hakkındaki görüşlerinin saptanması ve deneylerle zenginleştirilmiş fen derslerini ne ölçüde uygulayabildikleri araştırılmıştır. Ayrıca, öğretmenlerin deneyleri uygulama esnasında yaşadıkları sorunlara getirdikleri çözüm önerilerinin belirlenmesi amaçlanmıştır. Ek olarak, deneylerin öğrenme üzerine herhangi bir etkisinin olup olmadığına dair öğretmen görüşleri de alınmıştır. Bu genel amaç çerçevesinde aşağıdaki sorulara cevap aranmıştır.

\section{Araştırma Sorusu}

Kayseri ilinde görev yapan fen bilimleri öğretmenlerinin fen deneylerinin tasarımına, uygulama sürecine ve deneylerin öğrencilerin öğrenmeleri üzerindeki katkısına ilişkin görüşleri nelerdir?

\section{Alt Problemler}

- Fen bilimleri öğretmenlerinin fen deneylerinin uygulama sürecine ilişkin görüşleri nelerdir?

- Fen bilimleri öğretmenlerinin fen deneylerinin tasarımına ilişkin görüşleri nelerdir?

- Deneylerin öğrencilerin öğrenmeleri üzerindeki katkısına ilişkin fen bilimleri öğretmenlerinin görüşleri nelerdir? 


\section{Yöntem}

\section{Çalışmanın Deseni}

Araştırmada, nitel araştırma yöntemlerinden fenomonolojik (olgubilim) desen kullanılmıştır çünkü deneylerin uygulama, tasarım ve öğrencilerin öğrenme sürecine yönelik fen bilimleri öğretmenlerinin düşüncelerini ortaya çıkarmak amaçlanmıştır. İnsanlar, aynı olayları farklı şekilde anlayabilir ve yorumlayabilirler. Bu yüzden, olgubilim araştırmalarının konusu, insanların karşılaştıkları olgulardan ne algıladıkları ve deneyimlerinin neler olduğudur. Bir başka ifadeyle, olgubilim insanların bir olguyu anlarken ve yorumlarken ortaya koydukları farklı yolları tanımlar (Merriam, 2009; Yıldırım \& Şimşek, 2011).

\section{Çalışma Grubu}

Bu çalışma, 2014-2015 eğitim öğretim yılında Kayseri ilinde Millî Eğitim Bakanlığı'na bağlı ortaokullarda görev yapan ve lisansüstü eğitimlerine devam etmekte olan üç fen bilimleri öğretmeni ile yürütülmüştür. Katılımcılar, amaçlı örnekleme yöntemlerinden maksimum çeşitlilik örneklemesi ile belirlenmiştir. Buradaki amaç, küçük bir örneklem oluşturarak bireylerin çeşitliliğini maksimum derecede yansitmaktır. (Creswell, 2009; Patton, 2002). Bu amaçla, maksimum çeşitliliği yansıtacak şekilde Tablo-1'de özellikleri verilen öğretmenlerle çalışılmıştır. Araştırmada yer alan öğretmenler Ö1, Ö2 ve Ö3 şeklinde kodlanmıştır.

Tablo 1

Katılımcilara Ait Demografik Bilgiler

\begin{tabular}{lllll}
\hline Katılımcılar & Cinsiyet & Yaş & Kıdem & Ünvan \\
\hline Ö1 & Erkek & 28 & 6 yıl & Okul müdürü \\
Ö2 & Kadın & 24 & 1 yıl & Öğretmen \\
Ö3 & Kadın & 26 & 3 yıl & Öğretmen
\end{tabular}

\section{Veri Toplama Araçları}

Bu çalışmada veri toplama aracı olarak yarı yapılandırılmış görüşme formu kullanılmıştır. Yarı yapılandırılmış görüşme araştırmacıya ekstra soru sorma imkânı sunarak sağladığı esneklik nedeni ile tercih edilir (Glesne, 2010). Araştırmada görüşme formu soruları alan-yazından yararlanılarak oluşturulmuştur (Akgün, Gönen \& Yılmaz, 2005; Kuru \& Tatar, 2009; Taşkesenligil \& Tosun, 2012). Bu formda yer alan sorular, alanında uzman iki fen eğitimcisinin görüşleri doğrultusunda incelenmiş ve soru 1, soru 4, soru 7 ve soru 13 yeniden düzenlenmiştir. Ayrıca, soru 10 ile soru 15 birleştirilerek görüşme formuna son hâli verilmiştir. Görüşme formu iki bölümden oluşmuştur. Birinci bölümde katılımcıların kişisel özelliklerine ilişkin sorular, ikinci bölümde ise öğretmenlerin deney tasarımı ve uygulamaları ile deneylerin öğrencilerin öğrenmeleri 
üzerindeki katkısına ilişkin görüşlerini almak üzere hazırlanmış 15 adet açık uçlu soru bulunmaktadır. Görüşmeler ortalama 20 dakika sürmüştür. Görüşmeler, sessiz bir ortamda yapılmış ve ses kayıt cihazı ile kayıt altına alınmıştır. Görüşme, uygulamanın ardından metne dökülmüştür.

\section{Verilerin Analizi}

Görüşmelerden elde edilen verilerin analizinde, betimsel analiz kullanılmıştır. $\mathrm{Bu}$ amaçla, veriler daha önceden belirlenmiş temalara göre özetlenmiş ve yorumlanmıştır. Ayrıca, araştırmacılar bireylerin görüşlerini iç geçerliği artırmak amacıyla doğrudan alıntılarla sunmuştur. Böylece, bulgular okuyucuya özetlenmiş ve yorumlanmıştır (Yıldırım \& Şimşek, 2011). Yapılan analiz sonucunda Tablo 2'deki kategori, tema ve kodlar belirlenmiştir. Örneğin, görüşmenin ilk sorusu için uygulama açısından deneylerin düzeye uygun olup olmadığı sorulduğundan verilen cevaplara göre düzeye uygunluk kodu oluşturulmuştur. $\mathrm{Bu}$ kodun teması ise deney olarak belirlenmiştir.

Tablo 2

Görüşme Sonucu Elde Edilen Kategori, Tema ve Kodlar

\begin{tabular}{llll}
\hline Kategori & No & Tema & Kod \\
\hline & 1 & Deney & Düzeye uygunluk \\
& 2 & Uygulama durumu & Evet, Hayır \\
Uygulama & 3 & Uygulama ortamı & Yok \\
& 4 & Uygulamadaki güçlükler & Zaman, Mekân, Malzeme \\
& 5 & Deneylerin derse katkısı & Olumlu \\
& 6 & Öğretmen yeterliği & Yeterli, Eksik \\
\hline \multirow{2}{*}{ Tasarım } & 7 & Zümre öğretmeni & Katkısı var, Katkısı yok \\
& 8 & Kaynak çeşidi & Dergi, internet, kaynak kitap \\
\hline & 9 & Öğrenci katılımı & Aktif, Pasif \\
& 10 & Öğrenciye katkısı & $\begin{array}{l}\text { Akademik gelişim, Sosyal gelişim, Gerçek } \\
\text { hayatla bağlantı }\end{array}$ \\
& 11 & Tutum ve başarı & Olumlu \\
& 12 & Diğer derslerle ilişsi & $\begin{array}{l}\text { Matematik, Beden eğitimi, Din kültürü ve } \\
\text { ahlak bilgisi }\end{array}$ \\
\hline
\end{tabular}

\section{Geçerlik ve Güvenirlik}

İç geçerlik. İç geçerliği artırmak amacıyla, görüşmeler sessiz bir ortamda yapılmış ve ses kayıt cihazı ile kayıt altına alınmıştır. Daha sonra, görüşmeler metne 
dökülmüş ve bir kopyası da katılımcıya verilerek teyidi alınmıştır. Bu sayede katılımcı ile araştırmacılar uzun süreli etkileşim sağlamıştır. Ayrıca, oluşturulan görüşme formu uzman görüşüne sunulmuş ve gerekli düzeltmeler yapılmıştır. Bulgular kısmında ise katılımcıların ifadeleri doğrudan alıntılar yoluyla verilerek iç geçerlik artırılmıştır. Fakat bu çalışmada veri, örneklem, metot çeşitlemesi bulunmamaktadır.

Dış geçerlik. Araştırmadaki katılımcılara dair özellikler, araştırmanın yöntemi, bu yöntemin kullanılma nedeni ve veriler ayrıntılı bir şekilde sunularak dış geçerlik artırılmaya çalışılmıştır.

İç güvenirlik. Bulgular yorum yapılmadan doğrudan alıntı yapılarak verilmiştir ve oluşturulan kodlar-temalar uzman görüşüne sunularak gerekli düzeltmeler yapılmıştır.

Dış güvenirlik. Araştırmanın sonuçları ile bulgularının uygun olup olmadığını anlamak amacıyla bu iki bölüm alanında uzman iki fen eğitimcisine sunulmuştur.

\section{Bulgular}

Bulgular, Tablo 2 de verilen kategori ve temalar doğrultusunda ele alınmıştır. Bu temalardan elde edilen bulgular aşağıda kategori başlıkları dikkate alınarak sunulmuştur.

\section{Uygulama}

Deney teması altında, görüşmenin ilk sorusunda öğretmenlerin ders kitaplarında yer alan deneylere ilişkin görüşleri alınmıştır. Katılımcıların tümü ders kitaplarındaki deneyleri öğrencilerin düzeyine uygun bulurken Ö1 deneylerin çok vakit aldığını ve tamamını uygulayamadığını ifade etmiştir.

Görüşmede uygulama teması için ikinci olarak; "İlköğretim Fen Bilimleri Ders kitabında yer alan deneylerin hepsini uygulayabiliyor musunuz?" sorusu yöneltilmiş, verilen cevaplar incelendiğinde uygulanabilirlik açısından, Ö3 deneyleri uyguladığını belirtmiştir. Ö1 ve Ö2 ise her konuda deney yapamadıklarını ancak kolay temin edebildikleri malzemelerle yapabildikleri deneyleri uyguladıklarını söylemişlerdir. Ö3 bu durumu "okulumuzda malzeme var. O nedenle genellikle uygulamaya çalışlyorum. Hem onlar hazırlıkl gelsin hem de ben de hazırlıkl geleyim diye ögrrencilere o etkinlikleri dă̆ıtıyorum. Bu nedenle de çoğunlukla uygulayabiliyorum." şeklinde açıklamıştır. Ö2 ise "hayır, ben bir köy okulunda çalışıyorum. Orada yeterli malzeme yok. Hatta dinamometreyi de ben kendim temin ettim. Isterdim ki bu gösteri deneyi değil, tamamen öğrencilerin kendi yaptı̆̆l bir deney olsun. Bunun için de tabi ki malzeme gerekir. Hepsini yapmıyorum” demiştir.

Deneylerin uygulama ortamı açısından, öğretmenlerin karşılaştığı güçlükler irdelenmiş ve tüm katılımcılar okullarında laboratuvar bulunmadığını belirtmişlerdir. Ayrıca yeterli malzeme bulamadıklarından dolayı sıkıntı yaşadıklarını ifade etmişlerdir 
Üç katılımcı da zaman, mekân ve malzeme açısından yaşadıkları sıkıntılardan dolayı deneyleri uygulama esnasında güçlükler yaşadıklarını ifade etmişlerdir. Örneğin Ö3, zaman açısından sıkıntı yaşadığını, deneylerin uygulanmasının bir ders saatini kapsadığını ve bu durumda da konu olarak geride kaldığını belirtmiştir.

Görüşme esnasında, "Fen dersinde, deney uygulamaları öğrencilerin derse ve okula karşı ilgilerinde önemli bir değişikliğe neden oluyor mu?" sorusu sorulmuş ve katılımcıların tamamı öğrencilerin fen dersine yönelik ilgilerindeki değişimin olumlu yönde olduğunu belirtmişlerdir. Ö3, bu durumu, "o kadar ilginç etkinlikler var ki, hiç katılmayan ögrenci bile böyle benim yanıma gelmek istiyor. " cümleleriyle açıklamıştır.

Görüşmede öğretmen yeterliği irdelenmiş ve "Deneyleri uygularken fen alan bilgisi ve pedagojik alan bilginizin yeterli olduğunu düşünüyor musunuz?" sorusu yöneltilmiştir. Ö1 ve Ö2, fen ve pedagojik alan bilgilerinin yeterli olduğunu ifade etmişlerdir. Bu durumu, Ö2 “... Hem alan konusunda hem de formasyon konusunda eksiğim var, ama deneyi yapamayacak kadar değil. Zaten üniversitedeki laboratuvar derslerimizde de bunların birçoğunu yaptık" cümleleriyle açılamıştır. Ö3 ise alan bilgisinde eksiklik olduğunu "üniversitede gördügü̈müz şeyler burada kesinlikle bire bir yaşantıyı tam karşılamamıştır. Eksiklerim olduğunu da düşünüyorum. Üniversite eğitiminde kalite daha da artırılmalı sanıyorum. O kadar etkinlik var ki hiç görmediğimiz malzemeler var. Yeterli olduğunu düşünmüyorum." cümleleriyle açıklamıştır. Ö2 kendisini deneyleri uygulama sürecinde yeterli görmesine rağmen, Ö3 ile paralel olarak deneyleri uygulama sürecine ilişkin üniversite eğitiminin önemi üzerinde durmuş ve laboratuvar derslerinin üniversite eğitiminin son iki senesi yerine tüm dönemlere yayılması gerektiğini ifade etmiştir.

\section{Deney Tasarımı}

Çalışmanın ikinci araştırma sorusuna cevap vermesi açısından, deney tasarımına yönelik katılımcılara zümre öğretmenleriyle görüş alışverişinde bulunup bulunmadıkları sorulmuştur. $\mathrm{Bu}$ soruya Ö1 ve Ö2 okullarında zümre öğretmeni bulunmadığını ve tasarım açısından fikir alışverişi yapabilme imkânlarının olmadığını belirtmişlerdir. Ö3 ise okulunda ve görev yaptığı ilçedeki fen öğretmenleriyle iletişim hâlinde bulunduğunu belirtmiş ve bu durumun deney tasarımı sürecine olumlu yönde katkı sağladığını ifade etmiştir. Örneğin, deney tasarımında laboratuvardaki deney malzemelerinin nasıl kullanılacağına dair fikir sahibi olmadığı durumlarda farklı okullarda görev yapan fen bilimleri öğretmenleri ile fikir alışverişinde bulunduğunu belirtmiştir.

Deneyleri tasarlama aşamasında katılımcıların ders kitabı dışında ne tür kaynaklardan yararlandıkları araştırılmaya çalışılmıştır. Bu kapsamda Ö1, "Deneylerin olduğu bir dergi var. ... Fizik dergileri. O dergileri sıkça kullanıyorum." cümleleriyle açıklarken, Ö2 kodlu kadın katılımcı deneyler için kullandığ1 kaynak olarak internetten animasyonları izlediğini ve tasarım hakkında fikir aldığını belirtmiştir. Ayrıca, günlük yaşamda kullandığı malzemeleri deneyleri tasarlamak için kullandığını ifade etmiştir. Örneğin, eğik düzlem deneyi için cetvelle tasarım yaptığını şu cümlelerle açıklamıştır: “...Mesela tahtayla eğik düzlem yapmak gerekiyor, matematik sinıfindan bir tane cetvel 
allyoruz ve ters çeviriyoruz, rampa olarak kullanıyoruz. Altına kitap koyuyoruz ..." Suyun kaldırma kuvvetini gösteren deneyi tasarlama aşamasında ise okulunda ağırlık takımı, ip ve beher olmadığ1 için havan, bakır tel ve leğeni nasıl kullandığını şu cümlelerle açıklamıştır: “...Bizim ağırlık takımımız yoktu... Laboratuvarda havan var, onu kullandık. Onu ağırlık olarak ucuna astık, ipimiz yoktu ve kablo kullandık, kablonun içindeki bakırları çıkarttık ve onları sardık. Beherlerin ăgzı dardı, bizim o kadar ă̆ırlık takımımız olmadı̆̆ için çok geniş bir materyal oldu. Mutfaktan lĕgeni getirip kullandık..." Bir diğer kadın katılımcı olan Ö3 ise yararlandığı kaynakları "test kitapları (çalışma yaprakları olan etkinlik kitaplarını kastediyor) var orada da güzel etkinlikler var. Bu nedenle onları da kullandığım oluyor. ” şeklinde açıklamıştır.

\section{Öğrenme}

Çalışmanın üçüncü araştırma sorusuna cevap bulmak için deneylerin, öğrenci katılımı açısından öğrenmeye nasıl bir etkisinin olduğu sorulmuştur. Katılımcılardan Ö1 ve Ö3 anlamlı öğrenmenin olması için öğrencilerin deneylere aktif katılması gerektiğini, Ö2 ise aktif katılımın yanında pasif katılımın da anlamlı öğrenme açısından etkili olacağını savunmuşlardır. Ayrıca, katılımcıların tümü öğrencilerin bu süreçte aktif veya pasif olmalarının deney çeşidine göre değişebileceğini ifade etmişlerdir. Ö1 kodlu erkek kat1lımc1: "Bazı deneylerde sadece gösteri deneyleri yapılabilir. Yani deneylerin hepsini kesin çizgilerle çizmemek lazım. Kesinlikle gösteri, kesinlikle öğrencinin de katılacă̆ değil, bu deneylerin içinde öğrencilerin aktif katılacă̆g deneyler de olacak. Bazıları gösteri olması lazım, bazıları ögrencilerin katıldı̆̆ı deneyler olması lazım”.

Deneylerin öğrencilere katkısı hakkındaki katılımcı görüşleri akademik, sosyal ve gerçek hayat kodları altında ele alınmıştır. Ö1 deneylerin öğrencilere katkısının akademik ve sosyal yönden olduğunu "Fen deneyleri ögrencilerin bilimsel düşünme süreçlerini geliştiriyor. Bu da akademik katkı sağllyor. Deneyler yapıldıkça öğrenci sanki öğretmeni daha çok seviyor, sosyalleşiyor, ona karşı olumlu duygular geliştiriyor" cümleleriyle savunmuştur. Aynı katılımcı, fen konularının deneylerle omuz omuza gitmesi gerektiğini de ifade etmiştir. Gerekçe olarak da "....soyut kavramlar içeren fen bilgisi konuları deneylerle desteklenmesi durumunda somutlaştırılır, bu da anlamlı ögrenmeyi să̆lar. Bu nedenle etle tırnak gibi deneylerle fen ayrllmamalıdır." şeklinde düşüncelerini ifade etmiştir.

Ö1 ile benzer şekilde Ö2 de deneylerin öğrencilere katkısının akademik ve sosyal yönden olduğunu "konuyu daha iyi anlyyorlar. Hem akademik yönden hem sosyal açıdan çocukların gelişimine katkıda bulunduğunu düşünüyorum. Yani deneysiz fen olmaz" sözleriyle belirtmiştir.

Ö3 isimli katılımcı ise, bu konudaki fikrini "diyelim ki kitapta etkinlik olmasayd gerçekten etkinlik yapma gereği duyardım. Öğrenci orada anlamıyor, onu anlamasını nasıl sağlarım diye düşünerek, tabi ki kendim etkinlik bulurdum. " şeklinde belirtmiştir.

Ö3 ise diğerlerinden farklı olarak öğrencilerin gerçek hayatla bağlantı kurmada deneylerin faydalı olacağını ifade etmiştir. Bu durumu, "öğrenci gerçek hayatla bağlantı kuruyor. Mesela bir elektrik konusunda diyelim ki güç kaynă̆ı kullanıyor. Onu 
bir pille aynı şeyi yaptı̆̆ını fark etmesini sağllyor. Grupça yapılan etkinlikler var. $O$ etkinlikler sırasında öğrenciler birbirleriyle iletişime geçtiği için tabi ki sosyal açıdan ögretmenle, arkadaşlarıyla faydasını görüyorlardır. Öğrenciler dediğim gibi hiç derse ilgisi olmayan veya yeteneği olmayan öğrenciler olabilir. Ama etkinlikler öğrencilerin ilgisini çekiyor" ifadesiyle açıklamıştır.

"Deney sonrasında deneye katılan öğrencilerin fen bilimleri dersine karşı tutum ve başarıları açısından farklılık gözlemliyor musunuz?" ş̧eklinde öğretmenlere soru yöneltildiğinde, katılımcıların tamamı olumlu yönde bir değişim gözlediklerini belirtmişlerdir.

Görüşmelerde öğretmenlere deneylerin uygulanması esnasında diğer derslerdeki alan bilgisine ihtiyaç duyup duymadıkları sorulduğunda, üç katılımcı da özellikle matematik kavramlarına ihtiyaç duyduklarını belirtmişlerdir. Katılımcılara en çok hangi konunun işlenmesi esnasında matematik kavramlarına ihtiyaç duydukları sorulduğunda ise yine ortak bir cevap olarak sürat konusunda öğrencilerin konuyu anlayabildiklerini fakat matematiksel işlemler (dört işlem ve grafik yorumlama becerileri) kısmında eksiklik yaşadıklarını belirtmişlerdir. Ayrıca, Ö2 isimli katılımcı Ö1 ve Ö3 gibi fen konularını anlatırken matematik kavramlarına ihtiyaç duymuştur. Ayrıca, Ö2 din kültürü ve ahlak bilgisi ile beden eğitimi derslerinde bahsedilen kavramlara da ihtiyaç duyduğunu belirtmiştir. Ö2 bu durumu "din kültüründe bile öyle, mesela alkol konusu açıldı. .Ben fen öğretmeni olarak bunun sağlı̆̆ınıza bakan yönünü açıklıyorum ama din kültüründe farklı yönden yapıyor. Beden eğitimi dersinde de öyle, kaslarınızın çalıştı̆̆ını gösteriyoruz beden eğitimi dersinde bunların uygulamalarını yapabilirler." şeklinde açıklamıştır.

\section{Sonuç ve Tartışma}

\section{Uygulama}

Deneyleri uygulama süreci açısından öğretmenlerin görüşleri incelendiğinde, katılımcılar ders kitaplarındaki deneylerin öğrencilerin gelişim düzeyine göre hazırlandığını belirtmişlerdir. Benzer olarak, Aydın \& Çakıroğlu (2010) ve Erten (1993)'in çalışmalarında yer alan öğretmenler de ders kitaplarında yer alan deneylerin öğrencilerin öğrenme düzeyine uygun olduğunu ifade etmişlerdir. Fakat Aydoğdu \& Şırahane (2012), öğretmen adayları ile yaptıkları çalışmalarında deneylerin kitaplarda açık net ve anlaşılır olarak yazılmadığını düşünen öğretmen adaylarının oranını \%30 olarak belirtmişlerdir. $\mathrm{Bu}$ nedenle de çalışmalar arasında bu açıdan farklılık bulunmaktadır. Dolayısıyla, anlamlı öğrenmenin gerçekleşebilmesi için ders kitaplarının deneyler açısından öğrencilerin öğrenme düzeyine uygun olacak şekilde hazırlanması gerektiği sonucuna ulaşılabilir (Chang, \& Weng, 2000; Kang \& Wallace, 2005).

Öğretmenler, derslerinde deney uygulamalarına öğrencilerinin konuları daha iyi anlamalarını ve öğrenmelerini sağladığı için yer verdiklerini belirtmişlerdir. Bu çalışmanın sonuçlarından farklı olarak, Aydoğdu \& Şırahane (2012) öğretmenlerin laboratuar/alan bilgisi, tedbir alma, uygulama becerisi ve sınıfa hâkimiyet eksikliği ve Güneş, Şener, Germi \& Can (2013) ise zaman kaybı, laboratuvar ve araç-gereç 
yetersizliği bakımından deneyleri sınıflarında uygulamadıklarını tespit etmişlerdir. $\mathrm{Bu}$ çalışmada öğretmenlerin okullarında laboratuvar olmamasına rağmen deneyleri sınıflarında uyguluyor olmalarının nedeni olarak lisansüstü eğitim aldıkları için deneylerin öneminin farkında olmaları ve öğrencilerin anlamlı öğrenmelerine katkı sunma isteklerinin yüksek düzeyde olması gösterilebilir. Bu çalışmada uygulama ortamları olmamasına rağmen deneyleri uygulayan öğretmenler olmasına rağmen, bu durum her zaman böyle olmayabilir. Bu sebepten dolayı deneyleri uygulamak için laboratuvarların etkili ve malzemeler açısından yeterli olması gerekmektedir (Kang \& Wallace, 2005; Koç \& Bayraktar, 2013).

Öğretmenler deney uygulamaları esnasında karşılaştıkları güçlükleri zaman, mekân ve malzeme açısından değerlendirmişlerdir. Benzer olarak alan-yazında da, deneylerin uygulanmasındaki güçlükler olarak zaman (Buluş Kırıkkaya, 2009; Erten, 1993; Güneş \& diğerleri 2013; Kılıç, 2003; Uluçınar, Doğan \& Kaya, 2008), mekân (Uluçınar, Doğan \& Kaya, 2008) ve malzeme eksikliği (Buluş Kırıkkaya, 2009; Güneş \& diğerleri 2013; Koç \& Bayraktar, 2013; Uluçınar \& diğerleri 2008) tespit edilmiştir. Her ne kadar zaman, mekân ve malzeme açısından uygulamada sıkıntılar yaşansa da öğretmenlerin bunu bahane etmeden günlük yaşamdan basit malzemeler kullanarak derslerinde deneyleri uygulayabilirler. (Uysal \& Eryılmaz, 2002). Böylece, basit malzemeler öğrencilerin bu malzemeleri kullanabilme becerisini artırır ve deneylerin sonuçlarını yorumlamada onlara kolaylık sağlar (Haury \& Rillero, 1994).

$\mathrm{Bu}$ çalışmada, üç katılımcının görüşleri doğrultusunda deney uygulamalarının öğrencilere katkısına yönelik, deneylerin öğrencileri fen dersine karşı daha meraklı ve ilgili hale getirdiği sonucuna ulaşılmıştır. Benzer şekilde, Akpınar \& Ergin (2005) ve Koç \& Bayraktar, (2013) çalışmalarında deneylerin derse katkısının olumlu olduğunu ifade etmişlerdir. Örneğin, Akpınar \& Ergin (2005) dokuz öğrenci ile görüşme yaptıkları çalışmalarında, deneyler yaparak fen bilgisi dersini alan öğrencilerin fene karş1 tutumlarının, geleneksel öğretim ile öğrenim gören öğrencilere göre daha olumlu olduğunu belirtmişlerdir. Buradan da anlaşıldığ gibi öğrencilerin fene karşı ilgisini olumlu bir şekilde artırabilmek için sınıf içinde fen öğretmenlerinin deneyleri uygulamalarının gerekli olduğu görülmektedir.

Deneyleri uygulama sürecinde katılımcılardan ikisi uygulama sürecinde pedagojik alan bilgisi açısından kendilerini yeterli görmüşlerdir. Diğer katılımcı (Ö3) üniversitede aldığı laboratuvar derslerinin eksikliğini gerekçe göstererek kendisinin pedagojik alan bilgisini deneyleri uygulayabilme açısından yetersiz bulmuştur. Benzer olarak Erten (1993) çalışmasında öğretmenlerin deneyleri uygulama açısından yeterli ve yetersiz olarak sınıflamıştır. Buradan da görüldüğü gibi üniversite eğitimi esnasında laboratuvar derslerinde öğretmen adaylarına deneyleri daha fazla uygulama imkânı sağlanmalıdır (Güneş \& diğerleri 2013; Koç \& Bayraktar, 2013). Öte yandan, kendisini yeterli gören Ö2 bu durumu Kamu Personeli Seçme Sınavına (KPSS) fen alanına ait soruların eklenmesi ve bunun sonucunda bu alana daha dikkatli çalışmasıyla açıklamıştır. Dolayısıyla, laboratuvar kullanabilme ve deneyleri uygulayabilme 
açısından öğretmen adaylarının hatta öğretmenlerin belirli bir yeterlikte olmaları ve bu yeterliği kontrol edecek mekanizmaların bulunması gerekmektedir.

$\mathrm{Bu}$ çalışmada deney uygulamalarının fen öğretimindeki önemi çeşitli yönleriyle ele alınmıştır. Sonuç olarak, fen dersinde öğrencilerin yaparak- yaşayarak öğrenmelerini sağlaması amacıyla fen derslerinde deneylerin uygulanmasına ağırlık verilmelidir.

\section{Tasarım}

Zümre öğretmenleri ile fikir alışverişinde bulunmanın deney tasarımına yönelik katkısı olup olmadığ1 konusunda, diğer iki katılımc1 gibi Ö3 de okulunda başka fen bilimleri öğretmeninin bulunmadığını belirtmiştir. Bu yüzden katılımcılar okullarında deney tasarımı açısından diğer öğretmenlerden yardım alamadıklarını ifade etmişlerdir. Bununla birlikte Ö3, görev yaptığı ilçe merkezindeki diğer fen bilimleri öğretmenleri ile fikir alışverişinde bulunduğunu bunun da kendisine deney tasarımı açısından olumlu katkı sağladığını belirtmiştir. Özellikle göreve yeni başlayan fen bilimleri öğretmenlerinin deney tasarımına ilişkin bakış açılarının gelişmesi için okullarda diğer öğretmenlerle fikir alışverişlerinde bulunmaları büyük bir önem arz etmektedir. Ayrıca, bilindiği gibi göreve yeni başlayan fen bilimleri öğretmenlerine rehberlik edecek öğretmenler bulunması gerekmektedir. $\mathrm{Bu}$ rehber öğretmenlerinde fen bilimleri öğretmeni olması onların mesleki açıdan gelişimine olumlu yönde bir katkı sunacaktır.

Katılımcılar deney tasarımı için etkinlik kitapları, İnternet ve dergilerden yararlandıklarını ifade etmişlerdir. Deney tasarımına yönelik görüşleri alınan Ö2 okulda malzeme olmamasına rağmen, problem çözme ve yaratıcı düşünme becerisini kullanarak deney tasarımı yapabilmiştir. Buradan hareketle, fen bilimleri öğretmenleri okullarında deney malzemeleri bulunmamasını bir bahane olarak görmemeli ve günlük hayatta her yerden temin edilebilecek basit araç-gereçlerle deneylerini tasarlayabilmelidirler. Bir başka ifadeyle, onlar sadece ders kitaplarına bağlı kalmayıp, problem çözme ve yaratıcı düşünme becerilerini etkin bir şekilde kullanmalıdırlar (Aktamış \& Ergin, 2006; Uysal \& Eryılmaz, 2002). Öğretmenin basit malzemeler kullanarak deney tasarlaması ve sınıf içinde uygulaması öğrencileri sınıf içinde motive ettiği gibi sınıf dışında da onların kendi deneylerini tasarlamalarına 1şık tutacaktır (Uysal \& Eryılmaz, 2002). Ayrıca bu durum öğrencilerin bilimsel süreç becerilerini geliştirir (Mabie \& Baker, 1996; Wilke \& Straits, 2005).

\section{Öğrenme}

Katılımcıların düşüncelerine göre, öğrencilerin deneylere aktif olarak katılımlarının onların anlamlı öğrenmelerine katkı sunacağı sonucuna ulaşılmıştır. Benzer şekilde, Hançer, Şensoy \& Yıldırım (2003) ve Koç \& Bayraktar (2013) öğrencilerin aktif olmasını sağlayacak deneysel öğretim yöntemlerinin ve tekniklerinin fen derslerinde kullanılması gerektiğini ifade etmişlerdir. Bu nedenle, öğrencilerin aktif olmasını sağlayacak bu stratejiler kullanılmazsa anlamlı öğrenme gerçekleşmediği için onlar kendilerine sunulan yeni bilgileri ezberleme yoluna giderler ya da bilimsel olmayan kavram yanılgıları geliştirirler. Bu nedenle fen eğitimi ve öğretimi deneyleri 
göz ardı etmeden öğrencileri pasif konumdan aktif konuma getirebilecek şekilde planlanmalı ve uygulanmalıdır (Tiberghien \& diğerleri 2001; Tsai, 2003).

Güven \& Gürdal (2002), 64 katılımcı ile yaptıkları çalışmalarında, deneyle öğretim stratejisinin başarıyı arttırmada düz anlatım yöntemine göre daha etkili olduğunu tespit etmiştir. Bu çalışmada da görüşmelerden elde edilen verilere göre benzer şekilde, deneylerin öğrencilerin konuyu daha iyi algılamalarını sağladığı, akademik başarılarını artırdığı (Hofstein \& Mamlok-Naaman, 2007; Hofstein, Nahum \& Shore, 2001; Koray, Köksal, Özdemir, \& Presley, 2007; Uluçınar \& diğerleri 2004), sosyal gelişimlerini hızlandırdığı, tutumlarını olumlu yönde geliştirdiği (Erten, 1993; Koç \& Bayraktar, 2013) ve gerçek hayatla bağlantıyı kurmada onlara kolaylık sağladığı (Güneş \& diğerleri 2013) sonucuna ulaşılmıştır. Bir diğer çalışma olarak, Aydoğdu \& Ergin (2008) deneylerin, öğrencilerin bilimsel süreç beceri düzeylerini anlamlı bir fark oluşturacak düzeyde geliştirdiğini belirtmiştir. $\mathrm{Bu}$ araştırmada da benzer şekilde katılımcılar fen dersindeki deneylerin öğrencilerin bilimsel düşünme süreçlerini geliştirdiğini ve onların akademik başarılarına katkı sağladığını ifade etmişlerdir. Hançer, Şensoy \& Yıldırım (2003) ise deneylerle konuların desteklenmesi gerektiğini ve buluş yolu ile öğrencilerin sonuca ulaşmasının sağlanması gerektiğini ifade etmişlerdir. $\mathrm{Bu}$ nedenle deneyler fen bilgisi öğretmenleri tarafından önemsenmeli ve anlamlı öğrenmeye katkı sunacağı için bir öğretim stratejisi olarak kullanılmalıdır (Aydoğdu, 2000; Haury, \& Rillero, 1994).

Öğrenme açısından, deneylerle zenginleştirilmiş fen bilimleri dersinin diğer derslerle ilişkisinin önemli olduğu ve matematik dersi ile iş birliğinin deneylerin öğrenme üzerine katkısını artıracağ 1 sonucuna ulaşılmıştır. Örneğin, özellikle kuvvet ve hareket konularında yer alan deneylerde gerekli olan grafik çizimleri için öğrencilerin matematik dersinde öğrendiği "grafik çizimi ve yorumlanması" kazanımı onların deneylerin sonuçlarını yorumlamalarına katkı sağlayacaktır. Benzer şekilde, Çetin (2013) 345 fen öğretmen adayı ile yaptığı çalışmada, fen ve matematiğin sayısal dersler olarak iç içe olduğunu ve fendeki nicel ölçümlerin matematik bilmeden doğru bir şekilde ifade edilemeyeceğini belirtmişlerdir. Fen derslerinde bilimsel araştırma yöntemlerinin bilinmesinin yanında soyut düşünme becerilerinin önemi büyüktür. $\mathrm{Bu}$ nedenle matematikteki soyut değişkenlerin fen dersi ile ilişkilendirilmesi anlamlı öğrenmenin gerçekleşmesi için önemlidir (Çetin, 2013).

\section{Öneriler}

Çalışmada deneylerin uygulanması açısından özellikle zaman, mekân ve malzeme açısından çeşitli sıkıntıların çekildiği sonucuna ulaşılmıştır. Bu nedenle, fen bilimleri öğretmenlerinin deneyleri uygulayabilecekleri laboratuvarlar ya da benzeri ortamlar sağlanmalıdır. Okullarda deney malzemeleri temin edilmelidir. Öte yandan ders kitabı içeriğine basit malzemelerle yapılabilecek deneyler konulabilir ya da öğretmenler imkânları dâhilinde basit malzemeler ile yapılabilecek deneyleri tercih edebilirler. Programı yetiştirme bakımından da hazırlaması fazla zaman almayan deneyler tercih edilebilir. Ek olarak eğitim fakültelerinin fen ile ilgili lisans dersleri içeriklerine laboratuvar uygulamaları saatlerinin artırılması sağlanabilir. 
Deneylerin tasarlanması konusunda da katılımcıların sıkıntı çektiği görülmüştür. $\mathrm{Bu}$ nedenle, fen ders kitaplarının içeriğindeki deneylerin hazırlık ve yapılış aşamaları daha ayrıntılı yazılabilir ve bu kısımlar görsel öğelerle desteklenebilir. Deney tasarlama ve uygulama konusunda da hizmet-içi eğitim kursları düzenlenebilir.

$\mathrm{Bu}$ çalışmada deneylerin öğrencilerin anlamlı öğrenmelerine katk1 sağladığ1 sonucuna ulaşılmıştır. Bu nedenle, onların anlamlı öğrenmelerini artıracak şekilde fen bilimleri dersleri tasarlanmalı ve öğrencileri aktif kılacak deneylere dayalı öğretim stratejileri uygulanmalıdır.

$\mathrm{Bu}$ çalışmada veri toplama aracı olarak yarı yapılandırılmış görüşme kullanılmıştır. Bununla birlikte, gözlem ve doküman analizi de kullanılarak veri çeşitlemesi yapılabilir. Bu da iç geçerliği artıracaktır.

Bu konuda daha kapsamlı bir araştırma yapılabilir. Örneğin, sadece fen bilimleri öğretmenleri arasında değil, öğretmen adaylarıyla ve öğrencilerle yapılarak çalışma grubu genişletilebilir.

Deneylerin uygulanmasına yönelik nicel bir çalışma yapılıp, fen dersinde deney uygulamalarının öğrencilerin akademik başarılarına olan etkileri incelenebilir. 


\section{Kaynakça}

Abrahams, I., \& Millar, R. (2008). Does practical work really work? A study of the effectiveness of practical work as a teaching and learning method in school science. International Journal of Science Education, 30(14), 1945-1969.

Akgün, A., Gönen, S., \& Yılmaz, A. (2005). Fen bilgisi öğretmen adaylarının karışımların yapısı ve iletkenliği konusundaki kavram yanılgıları. Hacettepe Üniversitesi Eğitim Fakültesi Dergisi, 28, 1-8.

Akpınar, E., \& Ergin, Ö. (2005). Yapılandırmacı kurama dayalı fen öğretimine yönelik bir uygulama. Hacettepe Üniversitesi Eğitim Fakültesi Dergisi, 29, 9-17.

Aktamış, H., \& Ergin, Ö. (2006). Fen eğitimi ve yaratıc1lık. Dokuz Eylül Üniversitesi Buca Eğitim Fakültesi Dergisi, 20, 77-83.

Aktamış, H \& Ergin, Ö. (2007). Bilimsel süreç becerileri ile bilimsel yaratıcılık arasındaki ilişkinin belirlenmesi. Hacettepe Üniversitesi Eğitim Fakültesi Dergisi, $33,11-23$.

Aktamış, H., \& Şahin Pekmez, E. (2011). Fen ve teknoloji dersine yönelik bilimsel süreç becerileri ölçeği geliştirme çalışması. Buca Eğitim Fakültesi Dergisi, 30, 192 205.

Appleton, K. (Ed.). (2006). Elementary science teacher education: International perspectives on contemporary issues and practice. New Jersey: Lawrence Erlbaum Associates, Publishers.

Arı, E., \& Bayram, H. (2011). Yapılandırmacı yaklaşım ve öğrenme stillerinin laboratuvar uygulamalarında başarı ve bilimsel süreç becerileri üzerine etkisi. Illkögretim Online, 10(1), 311-324.

Ayas, A., Çepni, S., Akdeniz, A. R., Özmen, H., Yiğit, N. \& Ayvacı, H. Ş. (2005). Kuramdan uygulamaya fen ve teknoloji ögretimi. Ankara: Pegem Yayıncılık

Aydın, S., \& Çakıroğlu, J. (2010). İlköğretim fen ve teknoloji dersi öğretim programına ilişkin öğretmen görüşleri: Ankara örneği. İlköğretim Online, 9(1), 301-315.

Ayas, A., Çepni, S., Johnson, D., \& Turgut, M. F. (1997). Fizik öğretimi. Ankara: YÖK/Dünya Bankası Milli Eğitimi Geliştirme Projesi, Hizmet Öncesi Öğretmen Eğitimi.

Aydoğdu, C. (2000). Kimya öğretiminde deneylerle zenginleştirilmiş öğretim ve geleneksel problem çözme etkinliklerinin kimya ders başarısı açısından karşılaştırılması. Hacettepe Üniversitesi Eğitim Fakültesi Dergisi, 19, 29-31.

Aydoğdu, B., \& Ergin, Ö. (2008) Fen ve teknoloji dersinde kullanılan farklı deney tekniklerinin öğrencilerin bilimsel süreç becerilerine etkileri. Dokuz Eylül Üniversitesi, 9(2), 15-36.

Aydoğdu, B., \& Ergin, Ö. (2010). Fen ve teknoloji dersinde kullanılan farklı deney tekniklerinin öğrencilerin öğrenme yaklaşımlarına etkileri. In International Conference on New Trends in Education and Their Implications. Antalya, 11-13 Kasım, Turkey (s. 1019-1027). 
Aydoğdu, C., \& Şırahane, İ. T. (2012) Fen ve teknoloji öğretmen adaylarının laboratuvarda yaşanan kazaların nedenlerine yönelik görüşleri. X. Ulusal Fen ve Matematik Ĕgitimi Kongresi. Niğde: 27-30 Haziran, Türkiye.

Bilgin, İ., \& Karaduman, A. (2005). İşbirlikçi öğrenmenin 8. sınıf öğrencilerinin fen dersine karş1 tutumlarına etkisinin incelenmesi. İlköğretim Online, 4(2), 32-45.

Buluş Kırıkkaya, E. (2009). İlköğretim okullarındaki fen öğretmenlerinin fen ve teknoloji programına ilişkin görüşleri. Journal of Turkish Science Education, 6(1), 133-148.

Chang, C., \& Weng, Y. (2000). Exploring interrelationship between problem-solving ability and science-process skills of tenth-grade earth science students in Taiwan. Chinese Journal of Science Education, 8(1), 35-56.

Coştu, B., Ayas, A., Çalık, M., Ünal, S., \& Karataş, F.Ö. (2005). Fen öğretmen adaylarının çözelti hazırlama ve laboratuvar malzemelerini kullanma yeterliliklerinin belirlenmesi. Hacettepe Üniversitesi Eğitim Fakültesi Dergisi, 28, 65-72.

Creswell, J. W. (2009). Research design, qualitative, quantitative, and mixed methods approaches (3rd ed.). California: SAGE Publications.

Çetin, Ö. F. (2013). Fen bilgisi öğretmenliği öğrencilerine göre; neden matematik? Nasıl matematik?. Mehmet Akif Ersoy Üniversitesi Ĕ̆itim Fakültesi Dergisi, 1(25), 160-181.

Demirci, B. (1993). Çağdaş fen bilimleri eğitimi ve eğitimcileri. Hacettepe Üniversitesi Eğitim Fakültesi Dergisi, 9, 155-160.

Ergin, Ö., Şahin-Pekmez, E., \& Öngel Erdal, S. (2005), Kuramdan uygulamaya deney yoluyla fen ögretimi. İzmir: Dinazor Kitabevi.

Erten, S. (1993). Biyoloji laboratuvarlarının önemi laboratuvarlarda karşılaşılan problemler. Hacettepe Üniversitesi Ĕ̈itim Fakültesi Dergisi, 9, 315-330.

Geçer, A., \& Özel, R. (2012). İlköğretim fen ve teknoloji dersi öğretmenlerinin öğrenme-öğretme sürecinde yaşadıkları sorunlar. Kuram ve Uygulamada Eğitim Bilimleri, 12(3), 1-26.

Glesne, C. (2010). Becoming qualitative researchers: An introduction (4th ed.). Pearson Publication. USA.

Gömleksiz, M. N., \& Bulut, İ. (2007). Yeni fen ve teknoloji dersi öğretim programının uygulamadaki etkililiğinin değerlendirilmesi. Hacettepe Üniversitesi Ĕ̆itim Fakültesi Dergisi, 32, 76-88.

Güneş, M. H., Şener, N., Germi, N. T., \& Can, N. (2013) Fen ve teknoloji dersinde laboratuvar kullanımına yönelik öğretmen ve öğrenci değerlendirmeleri. Dicle Üniversitesi Ziya Gökalp Ĕ̈itim Fakültesi Dergisi, 20, 1-11.

Gürdal, A. (1991). İlkokul fen eğitiminde laboratuvar ve araç kullanımı. M. ̈̈. Atatürk Ĕ̈itim Fakültesi Ĕ̆itim Bilimleri Dergisi, 3, 145-155. 
Güven, İ., \& Gürdal, A. (2002). Ortaöğretim fizik derslerinde deneylerin öğrenme üzerindeki etkileri. V. Ulusal Fen Bilimleri Ve Matematik Eğitimi Kongresi. 16-18 Eylül. ODTÜ: Ankara.

Hadson, D (1998). Towards a philosophically more valid science curriculum. Science Education, 72, 19-40.

Hançer, A. H., Şensoy, Ö., \& Yıldırım, H. İ. (2003). İlköğretimde çağdaş fen bilgisi öğretiminin önemi ve nasıl olması gerektiği üzerine bir değerlendirme. Pamukkale Üniversitesi Ĕ̌itim Fakültesi Dergisi, 13(13), 80-88.

Haury, D. L., \& Rillero, P. (1994). Perspectives of hands-on science teaching, 02.03 .2015

tarihinde

http://www.ncrel.org/sdrs/areas/issues/content/cntareas/science/eric/eric-2.htm adresinden erişildi.

Hofstein, A. \& Lunetta, N. V. (2004). The laboratory in science education: foundations for the twenty-first century, Science Education, 88, 28-54.

Hofstein, A. \& Mamlok-Naaman, R. (2007). The laboratory in science education: the state of the art. Chemistry Education Research and Practice, 8(2), 105-107.

Hofstein, A., Nahum, T. L. \& Shore, R. (2001). Assessment of the learning environment of inquiry-type laboratories in high school chemistry. Learning Environments Research, 4, 193-207.

Huppert, J., Lomask, S.M. \& Lazarowitz, R (2002). Computer simulations in the high school: Students' cognitive stages, science process skills and academic achievement in microbiology. International Journal of Science Education, 24(8), 803-821.

Kang, N. H., \& Wallace, C. S. (2005). Secondary science teachers' use of laboratory activities: Linking epistemological beliefs, goals, and practices. Science Education, 89(1), 140-165.

Kanlı, U., \& Yağbasan, R. (2008). 7E modeli merkezli laboratuvar yaklaşımının öğrencilerin bilimsel süreç becerilerini geliştirmedeki yeterliliği. Gazi Ĕ̆gitim Fakültesi Dergisi, 28(1), 91-125.

Kavak, N., \& Köseoğlu, F. (2001). Fen öğretiminde yapılandırıcı yaklaşım

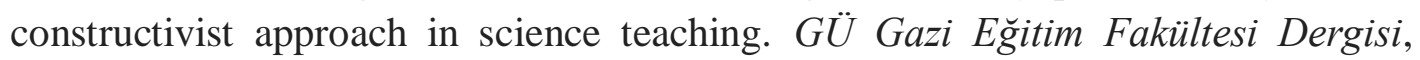
21(1), 139-148.

Kılıç, G. B. (2003). Üçüncü uluslararası matematik ve fen araştırması (TIMSS): Fen öğretimi, bilimsel araştırma ve bilimin doğası. Illköğretim - Online 2(1), 42-51.

Kocakülah, A., \& Savaş, E. (2011). Fen bilgisi öğretmen adaylarının deney tasarlama ve uygulama sürecine ilişkin görüşleri. Ondokuz Mayıs Üniversitesi Eğitim Fakültesi Dergisi, 30(1), 1-28.

Koç, B., \& Bayraktar, Ş. (2013). Sınıf öğretmenlerinin 4. ve 5. sınıf fen ve teknoloji dersi deneylerine yönelik görüşleri ve uygulamaları. Sosyal Bilimler Dergisi, 15(1), 129-154. 
Koray, Ö., Köksal, M. S., Özdemir, M., \& Presley, A. İ. (2007). Yaratıcı ve eleştirel düşünme temelli fen laboratuarı uygulamalarının akademik başarı ve bilimsel süreç becerileri üzerine etkisi. Ilköğretim Online, 6(3), 377-389.

Kuru, M. \& Tatar, N. (2009). Açıklamalı yöntemlere karşı araştırmaya dayalı öğrenme yaklaşımı: ilköğretim öğrencilerinin fen bilgisi dersine yönelik tutumlarına etkileri. Pamukkale Üniversitesi Ĕgitim Fakültesi Dergisi, 25(25), 153-165.

Millı̂ Eğitim Bakanlığı. (2005). İlköğretim Fen ve Teknoloji Dersi Öğretim Programı. Ankara.

Lagowski, J.J. (1989). Reformating the laboratory. Journal of Chemical Education. 66(1), 12-14.

Mabie, R., \& Baker, M. (1996). A comparison of experiential instructional strategies upon the science process skills of urban elementary students. Journal of Agricultural Education, 37, 1-7.

Merriam, S. B. (2009). Qualitative research (Second edition). San Francisco: JosseyBass.

Myers, B.E. (2004). Effects of investigative laboratory integration on student content knowledge and science process skill achievement across learning styles. (Unpublished doctoral dissertation). University of Florida.

Özmen, H. (2004). Fen öğretiminde öğrenme teorileri ve teknoloji destekli yapılandırmac1 (constructivist) öğrenme. The Turkish Online Journal of Educational Technology, 3(1), 100-111.

Patton, M. Q. (2002). Qualitative research and evaluation methods (Third Edition). California: Sage Publications, USA.

Tan, M. \& Temiz, B. K. (2003). Fen öğretiminde bilimsel süreç becerilerinin yeri ve önemi. Pamukkale Üniversitesi Ĕ̈itim Fakültesi Dergisi,13(13), 89-101.

Taşkesenligil, Y., \& Tosun, C. (2012). Probleme dayalı öğrenme yönteminin öğrencilerin kimya dersine karşı motivasyonlarına ve öğrenme stratejilerine etkisi. Türk Fen Ĕ̈itimi Dergisi, 9, 104-125.

Tiberghien, A., Veillard, L., Le Maréchal, J. F., Buty, C., \& Millar, R. (2001). An analysis of lab work tasks used in science teaching at upper secondary school and university levels in several European countries. Science Education, 85(5), 483-508.

Tsai, C. (2003) Taiwanese science students' and teachers' perceptions of the laboratory learning environments: Exploring epistemological gaps, International Journal of Science Education, 25(7), 847-860.

Turpin, T. \& Cage, B. N. (2004). The effects of an integrated activity-based science curriculum on student achievement, science process skills and science attitudes. Electronic Journal of Literacy through Science. 3, 1-15.

Uluçınar, Ş., Cansaran, A., \& Karaca, A. (2004). Fen bilimleri laboratuvar uygulamalarının değerlendirilmesi. Türk Ĕgitim Bilimleri Dergisi, 2(4), 465-475. 
Uluçınar, Ş., Doğan, A., \& Kaya, O. N. (2008) Sınıf öğretmenlerinin fen öğretimi ve laboratuvar uygulamalarına ilişkin görüşleri. Kastamonu Eğitim Dergisi,16(2), 485494.

Ulukök, Ş., Çelik, H., \& Sarı, U. (2013). Basit elektrik devreleriyle ilgili bilgisayar destekli uygulamaların deneysel süreç becerilerinin gelişimine etkisi. Kuramsal Eğitimbilim Dergisi, 6(1), 77-101.

Uysal, E \& Eryılmaz, A. (2002). Newton'un 1. ve 3. hareket yasalarıla ilgili günlük hayattan basit malzemelerle deneyler. V. Ulusal Fen ve Matematik Eğitimi Kongresi. 16-18 Eylül. ODTÜ: Ankara.

Uzun, N., \& Sağlam, N. (2005). Genetik konularının öğreniminde deney uygulamalarının akademik başarıya etkisi. Hacettepe Üniversitesi Eğitim Fakültesi Dergisi, 28, 196-200.

Ünal, G., \& Ergin, Ö. (2006). Buluş yoluyla fen öğretiminin öğrencilerin akademik başarılarına, öğrenme yaklaşımlarına ve tutumlarına etkisi. Türk Fen Eğitimi Dergisi, 3(1), 36-52.

Van Driel, J. H., Beijaard, D., \& Verloop, N. (2001). Professional development and reform in science education: The role of teachers' practical knowledge. Journal of research in science teaching, 38(2), 137-158.

Wilke, R. R. \& Straits, W. J. (2005). Practical advice for teaching inquiry-based science process skills in the Biological sciences. The American Biology Teacher, 67(9), 534-540.

Wu, H. K., \& Krajcik, J. S. (2006). Inscriptional practices in two inquiry-based classrooms: A case study of seventh graders' use of data tables and graphs. Journal of Research in Science Teaching, 43(1), 63-95.

Yıldırım, A. \& Şimsek, H. (2011). Sosyal bilimlerde nitel araştırma yöntemleri (Sekizinci basım). Ankara: Seçkin Yayıncılık.

YÖK/Dünya Bankası, (1997). Milli Eğitimi Geliştirme Projesi Hizmet Öncesi Öğretmen Eğitimi, Ankara. 